\title{
Feeding Experiments with Decomposition Products of Proteins.
}

\author{
By \\ Shiro MaEda. \\ (Biochemical Laboratory, Institute of Physical and Chemical Research, Tokyo)
}

(Received July 22, 1932.)

It is now generally assumed that protein in food is in a greater part hydrolysed in the alimentary canal into amino acids and again regenerated to the body protein, specific to each individual organism, so it is very probable that food protein can be substituted by the mixture of amino acids, provided that all necessary amino acids are present in adequate proportion. Abderhalden ${ }^{(1)}$ was the first who tried to settle this problem by feeding experiment. In one experiment with a dog fed on the enzymatic decomposition products of lean meat, prepared by treating with pepsin, trypsin and erepsin successively, he has demonstrated that nitrogen equilibrium was maintained for many weeks. In another experiment with a dog, previously starved and lost a greater part of the body weight, he has observed that by giving the same decomposition products, the animal not only recovered the health but the body weight attained higher than before experiment. In a later period, he gave the mixture of amino acids to the same dog and observed that the nitrogen balance was still maintained, though for a short time.

$U$. Suzuki ${ }^{(2)}$ reported also the positive results obtained with white rats fed on the synthetic diets containing either pepton or erepton. But he could not obtain any satisfactory results with the acid or baryta hydrolytic products. In this experiments a portion of meat protein was boiled with $25 \%$ sulphuric acid for 20 hours, sulphuric acid was carefully removed by baryta and evaporated to dryness. Another portion of meat protein was boiled with saturated baryta solutien for 6 hours and after removing baryta with sulphuric acid, evaporated to dryness. By adding these decomposition products, either alone or in combination, to the extent of $10 \%$ of the protein-free synthetic diet, otherwise adequate for growth, the rats could not maintain the health and gradually lost their body weights until finally succumbed.

Mitchell ${ }^{(3)}$, McClendon ${ }^{(4)}$ and Rose $^{(5)}$ have recently reported the results of

(1) Abderhalden: Z. physiol. Chem., 42 83 (1904 1913).

(2) U. Suzuki : J. Chem. Soc. Tokyo., 41, 5 (1920), 381.

(3) Mitchell: J. biol. Chem., 26 (1916), 231.

(4) McClendon: Proc. Soc. Exper. Biol. \& Med., 28 (1930 1931), 915.

( 5 ) Rose: J. biol. Chem., 92 (1931), ixvi. 
the similar experiments with mice and white rats fed on the synthetic diet containing the mixture of all known amino acids. The rats remained healthy for a month keeping their original body weights, but afterwards gradually declined.

We see thus that further experiments on this subject are desirable. From such a point of view, the present author has carried out some preliminary experiments with white rats, supplying the diets, in which the whole of the protein has been replaced by its partial or complete decomposition products.

In the first place, the enzymatic digestion products, such as Witte's peptone and Teruuchi's peptone were used and these were proved to be capable of replacing the dietary protein completely.

In the next experiments with the sulphuric acid and the baryta hydrolytic products of various degrees it was shown that neither the acid products alone, nor those by baryta could give any satisfactory results, but the mixture of the both was proved to be able to substitute the protein completely.

It is will known that the tryptophane in the protein molecule is completely destroyed by boiling with strong sulphuric acid, but it is not decomposed by baryta, though it undergoes racemization. Further it has been confirmed by several authors that tryptophane is one of the indispensable amino acids for building up the body protein, and it can not be substituted with any other amino acids. Taking these facts in consideration, the auther has carried out further experiments in which the acid hydrolysates were supplemented with tryptophane, instead of the baryta hydrolysates and came to the conclusion that tryptophane is the only factor which is lacking in the acid hydrolysates. By supplying it to the extent of $3 \%$ to the latter, the rats could secure the normal growth just like in the case, when the baryta hydrolysates were supplied.

Further experiments with the mixture of purified amino acids are now going on.

\section{Experimental.}

I. Experiments with digestion products by enzymes.

Commercial Witte's peptone (the pepsin digest of fibrin) and Teruuchi's peptone (the trypsin digest of casein) were used in this experiments, in the latter case $1 \%$ of cystine being added. The both are the mixtures of proteose and peptone, giving a specific biuret reaction. The analysis gave the following results. 


\begin{tabular}{l|c|c|c|c|c}
\hline \multirow{2}{*}{} & \multirow{3}{*}{ N\% } & \multicolumn{4}{|c}{ Amino-N\% } \\
\cline { 3 - 6 } & & Van Slyke's Method & \multicolumn{2}{|c}{ Formol method } \\
\cline { 2 - 6 } & & Subst. \% & N\% & Subst. \% & N\% \\
\hline Witte's peptone & 16.28 & 1.69 & 10.39 & 1.13 & 6.94 \\
Teruuchi's peptone & 13.23 & 3.81 & 28.80 & 4.31 & 32.58 \\
\hline
\end{tabular}

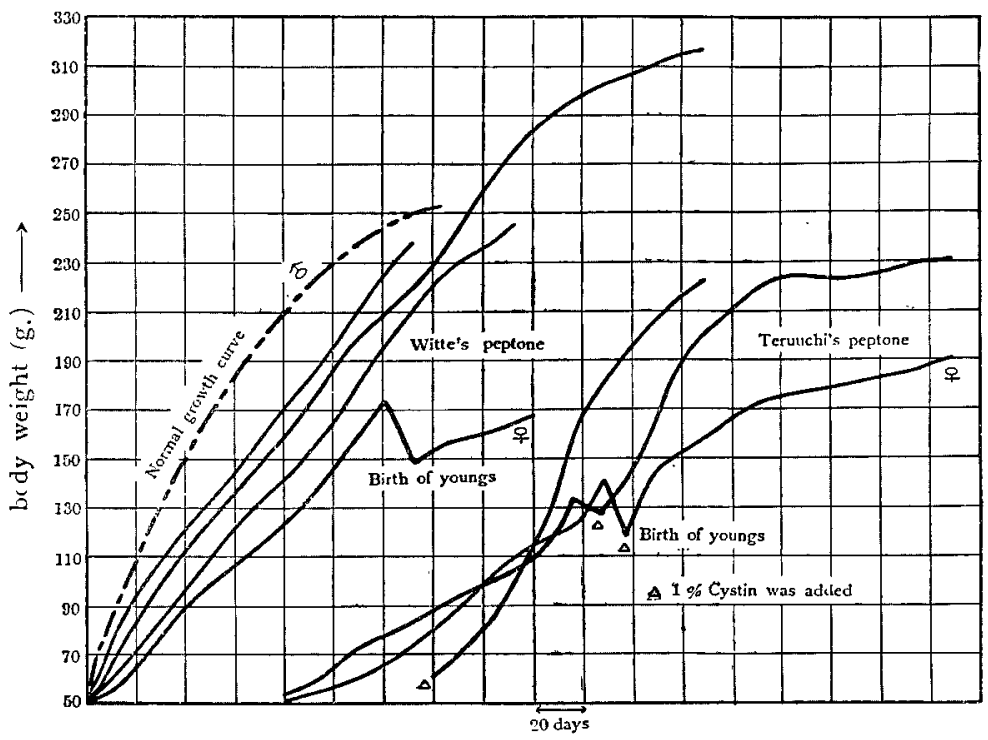

Fig. I.

Young albino rats were fed on the ration consisting of:

$\begin{array}{llll}\text { Each peptone } & 10 \% & \text { Starch } & 70 \% \\ \text { Butter } & 15 \% & \text { McCollum's salt mixture 5\% } \\ \text { Oryzanin } & 5 \mathrm{cc} \text { per } 100 \mathrm{~g} . & \end{array}$

In both cases the rats grew normally and increased in body weights from 50 $\sim 60 \mathrm{~g}$. to more than $200 \mathrm{~g}$. in 3 months (Fig. I).

II. Exporiments with the acid and the baryta hydrolytic products.

(1) Experiments with hydrolytic products of fish meat protein.

The meat protein from codfish (total $\mathrm{N} 16 \cdot 11 \%$ by Kjeldahl's method) was boiled with 6 times its quantity of $25 \%$ sulphuric acid for 30 hours, until it gave no biuret reaction, and showed no more increase of amino-nitrogen when boiled further for an hour. The second and the third portions were hydrolysed partially for one and ten hours respectively, besides the forth one was digested with $70 \%$ sulphuric acid at room temperature for 1 week, until 
the greater part of the protein was converted into peptone $e^{(6)}$.

Another portion of the fish meat protein was boiled with 6 times its quantity of hot saturated baryta" solution for 60 hours. The hydrolysate was free from biuret reaction, and showed no change in amino-nitrogen value when boiled further for one hour. Still other two protions were hydrolysed partially by baryta for one and ten hours respectively.

Sulphuric acid or baryta in each hydrolysed solution was quantitatively removed by baryta or sulphuric acid respectively, each filtrate from barium sulphate was neutralized with dilute sodium hydroxyde solution and then evaporated to dryness at lower tempesature. In each case $85 \sim 95 \mathrm{~g}$. of the hydrolytic products were obtained from $100 \mathrm{~g}$. of the protein. The analysis of these products gave the following results.

\begin{tabular}{|c|c|c|c|c|c|c|c|c|c|}
\hline \multirow{3}{*}{$\begin{array}{l}\text { Condition } \\
\text { of } \\
\text { decomposition }\end{array}$} & \multirow{3}{*}{ 兽 } & \multirow{3}{*}{ N\%ó } & \multicolumn{4}{|c|}{ Amino- $\mathrm{N} \%$} & \multicolumn{3}{|c|}{ Rutation } \\
\hline & & & \multicolumn{2}{|c|}{$\begin{array}{l}\text { Van Slyke's } \\
\text { method }\end{array}$} & \multicolumn{2}{|c|}{$\begin{array}{l}\text { Fornoul } \\
\text { method }\end{array}$} & \multirow{2}{*}{$\begin{array}{c}\text { Subst. } \\
\text { g. in } \\
100 \text { c.c. } \\
\left.\mathrm{H}_{2} \mathrm{O}\right)\end{array}$} & \multirow{2}{*}{$\alpha$} & \multirow{2}{*}[a]{$_{11}^{260}$} \\
\hline & & & $\begin{array}{c}\text { Subst } \\
\%\end{array}$ & N\% & $\begin{array}{c}\text { Subst } \\
\%\end{array}$ & N\% & & & \\
\hline $\begin{array}{l}\text { by } 70 \% \mathrm{H}_{2} \mathrm{SO}_{4} \\
\text { at room tenp. }\end{array}$ & + & 15.99 & 4.62 & 28.93 & 2.47 & 15,42 & 3.2413 & -1.65 & -50.93 \\
\hline $\begin{array}{l}\text { by } 25 \% \mathrm{H}_{2} \mathrm{SO}_{4} \\
\text { for } 1 \mathrm{hr} \text {. }\end{array}$ & + & 16.02 & 7.93 & 49.48 & 6.46 & 40.35 & 3.0727 & -0.68 & -22.13 \\
\hline "', " $10 \mathrm{hrs}$ & - & 16.02 & 11.71 & 73.11 & 10.82 & 67.56 & 3.2084 & +0.31 & +9.67 \\
\hline$" \quad$ " $30 \mathrm{hrs}$. & - & 15.95 & 13.01 & 83.43 & 12.91 & 80.95 & 2.9435 & +0.31 & +10.53 \\
\hline $\begin{array}{l}\text { by baryta, } \\
\text { for } 1 \mathrm{hr} \text {, }\end{array}$ & + & 14.55 & 12.16 & 83.58 & 12.03 & 82.68 & 3.0861 & 0.00 & 0.00 \\
\hline$" \prime, ", 10 \mathrm{hrs}$. & - & 14.43 & 13.60 & 94.28 & 13.33 & 92.32 & 3.1411 & 0.00 & 0.00 \\
\hline$"$, " $30 \mathrm{hrs}$ & 一 & 14.33 & 14.05 & 98.00 & 13.55 & 94.58 & 3.6026 & 0.00 & 0.00 \\
\hline
\end{tabular}

Millon's, xanthoproteic and Pauly's reaction were positive in all of the above products. Ehrlich's tryptophane reaction by $p$-dimethyl-aminobenzaldehyde was positive with all of the baryta hydrolytic products. With the decomposition products by $70 \%$ sulphuric ac ${ }^{i} \mathrm{~d}$ and those by $25 \%$ sulphuric acid for 1 hour the reaction was slightly positive, while the remaining two acid hydrolytic products gave entirely negative results. Sulphur reaction and the Sakaguchi's reaction for arginine were distinctly positive with the acid hydrolysates, but were entirely negative with the baryta hydrolysate.

Jaffe's rection for amino acid anhydride by picric acid and sodium carbonate were positive, except with the baryta hydrolysate and the $25 \%$ sulphuric acid hydrolysate for 30 hours.

From these colour reaction, it can be seen that in the acid hydrolysis,

(6) Fischer \& Abderhalden: B., 39 (1906), 752.

* Baryta was recrystallized carefully. 
tryptophane was destroyed, while in the baryta hydrolysis, cystine and arginine were decomposed, besides, the presence of amino acid anhydrides, in the partial hydrolytic products by sulphuric acid was indicated. Moreover, it can be seen that the protein loses its optical activity within an hour, when boiled with baryta.

Feeding experiments were carried out with the diets consisting of

\begin{tabular}{|c|c|c|}
\hline Acid hydrolytic products & $8 \%$ & Butter \\
\hline Baryta hydrolytic products & $8 \%$ & McCollum's salt mixture \\
\hline Starch & $65 \%$ & Oryzanin $\quad 5$ c.c. p \\
\hline
\end{tabular}

The combination of the hydrolytic products was as follows:

Acid hydrolytic products prepared by :

I. $70 \% \mathrm{H}_{2} \mathrm{SO}_{4}$ at room temperature + Baryta for 1 hour.

II. $25 \% \mathrm{II}_{2} \mathrm{SO}_{4}$ for 1 hour + Baryta for 1 hour.

III. $25 \% \mathrm{H}_{2} \mathrm{SO}_{4}$ for 10 hours + Baryta for 10 hours.

IV. $25 \% \mathrm{H}_{2} \mathrm{SO}_{4}$ for 30 hours + Baryta for 60 hours.

Besides, a diet of the following composition, containing the fish meat protein was used for the control.

\begin{tabular}{|c|c|c|}
\hline Fish meat protein & $10 \%$ & McCullum's salt mixture $5 \%$ \\
\hline Starch & $70 \%$ & Oryzanin 5 c.c. per $100 \mathrm{~g}$. \\
\hline Butier & $15 \%$ & \\
\hline
\end{tabular}

Rats fed on the above diets grew healthy and increased in weight from 40 $\sim 50 \mathrm{~g}$. to $130 \sim 160 \mathrm{~g}$. in two months, though the rate of growth was much slower than that of the control animals (Fig. II).

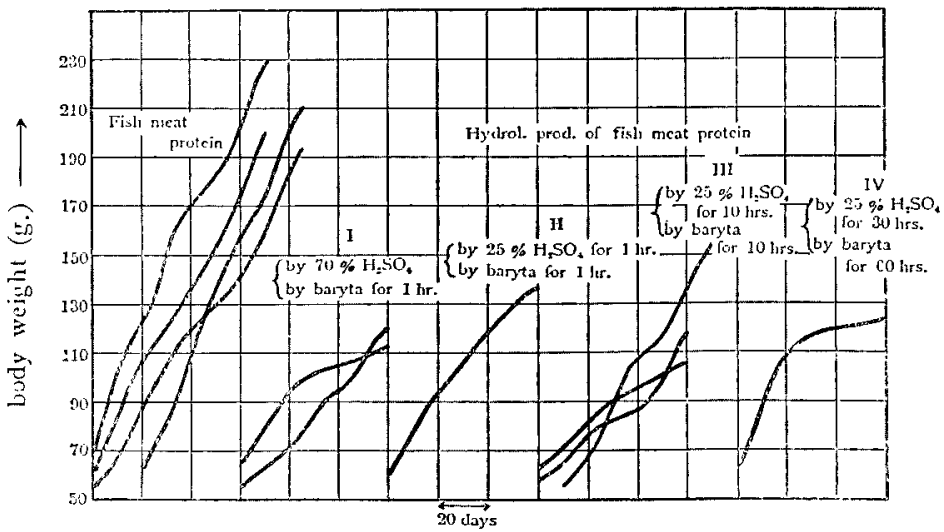

Fig. II.

The fact were worthy of note, that the products hydrolysed by sulphuric acid for 30 hours and those by baryta for 60 hours were free from biuret reaction, and showed, only slight increase in amino-nitrogen value, when boiled further for 5 hours with $20 \% \mathrm{HCl}$, as shown in the following example. 
(i) The hydrolytic products of fish meat protein (by $25 \%$ sulphuric acid for 30 hours), were boiled further for 5 hours with $20 \% \mathrm{HCl}$, and the amino$\mathrm{N}$ was estimated as follows :

\begin{tabular}{|c|c|c|c|c|}
\hline & \multicolumn{4}{|c|}{ Amino-N $\%$} \\
\hline & \multicolumn{2}{|c|}{ Van Slyke's method } & \multicolumn{2}{|c|}{ F'ormol method } \\
\hline & Subst. \% & $\mathrm{N} \%$ & Subst. $\%$ & $N \% 6$ \\
\hline Before boiling with $\mathrm{HCl}$ & 13.25 & 83.31 & 12.91 & 81.00 \\
\hline After " $" \prime \prime$ & 13.58 & 85.19 & 12.91 & 81.00 \\
\hline Increase & 0.33 & 1.88 & 0.00 & 0.00 \\
\hline
\end{tabular}

(ii) The hydrolytic products of fish meat protein (by hot saturated baryta solution for 60 hours), were boiled further for 5 hours with $20 \% \mathrm{HCl}$, and analysed as follows :

\begin{tabular}{|c|c|c|c|c|}
\hline & \multicolumn{4}{|c|}{ Amino-N \% } \\
\hline & \multicolumn{2}{|c|}{ Van Slyke's method } & \multicolumn{2}{|c|}{ Formol method } \\
\hline & Subst. \% & $\mathrm{N} \%$ & Subst. 午 & Nó \\
\hline Before boiling with $\mathrm{HCl}$ & 14.06 & 98.10 & 13.47 & 94.00 \\
\hline After & 14.29 & 99.81 & 13.75 & 95.92 \\
\hline Increase & 0.23 & 1.71 & 0.28 & 1.92 \\
\hline
\end{tabular}

Feeding experiments were repeated with the mixture of the above hydrolytic products i.e. with the mixture IV. As the source of vitamin B, first oryzanin and then the alcohol extract of yeast were used. The yeast extract was prepared acording to Williams and Watermann ${ }^{(7)}$. The extract itself or its precipitable part by phosphotungstic acid gave no biuret reaction. 100 c.c. of this extract yielded $12.4875 \mathrm{~g}$. of dry matter and $0.7624 \mathrm{~g}$. of nitrogen, the percentage of nitrogen in the dry matter being $6.11 \%$. No noticeable increase was observed by boiling with $20 \% \mathrm{HCl}$ for 5 hours more, indicating that almost all of the nitrogen were present in non-peptide form.

\begin{tabular}{c|c|c|c|c}
\hline \multirow{2}{*}{} & \multicolumn{4}{|c}{ Amino-N \% } \\
\cline { 2 - 5 } & \multicolumn{2}{|c|}{ Van Slyke's method } & \multicolumn{2}{|c}{ Formol methud } \\
\cline { 2 - 5 } & Subst. \% & N\% & Subst. \% & N\% \\
\hline Before boiling with HCl & 3.85 & 63.00 & 4.65 & 76.03 \\
After " " & 3.86 & 63.24 & 4.68 & 76.60 \\
Increase & 0.01 & 0.24 & 0.03 & 0.57 \\
\hline
\end{tabular}

(7) Willams \& Watermann: J. Biol, Chem., 86 (1930). 275. 
Two rats fed on the above diet grew normally from $56 \mathrm{~g}$. and $62 \mathrm{~g}$. up to $330 \mathrm{~g}$. and $230 \mathrm{~g}$. respectively in 8 months (Fig. III, VII, VIII, IX).

(2) Experiments with decomposition products of casein.

Similar experiments were carrid out with the biuret free decomposition products of casein by sulphuric acid and those by baryta. Rats grew from $62 \mathrm{~g}$. and $73 \mathrm{~g}$. to $91 \mathrm{~g}$. and $100 \mathrm{~g}$. respectively in 2 months, though the results were less satisfactory than the preceding experiments (Fig. III).

(3) Experiment with decomposition products of horse meat protein.

To the rats, previously fed on the casein decomposition products for 2 months, the mixture of the biuret-free hydrolytic products of horse meat protein by sulphuric acid and those by baryta were given. Rats grew vigorously as in the case with the hydrolytic products of the fish meat protein, and increased in weight up to $192 \mathrm{~g}$. and $220 \mathrm{~g}$. in 2 months (Fig. III, X, XI).

In the control experiment giving a protein free diet, the rat died within 20 25 days with a remarkable loss of weight. By giving water only without diet, the rats died within $2 \sim 3$ days (Fig. III). The protein free diet referred to above had the following composition.

$\begin{array}{lll}\text { Starch } & 75 \% & \text { McCollum's salt mixture } 5 \% \\ \text { Butter* } & 20 \% & \text { Oryzanin } 5 \text { c.c. per } 100 \mathrm{~g} . \\ \text { Total } N \text { of starch : } & 0.04 \% & \text { Total } N \text { of butter : } 0.09 \%\end{array}$

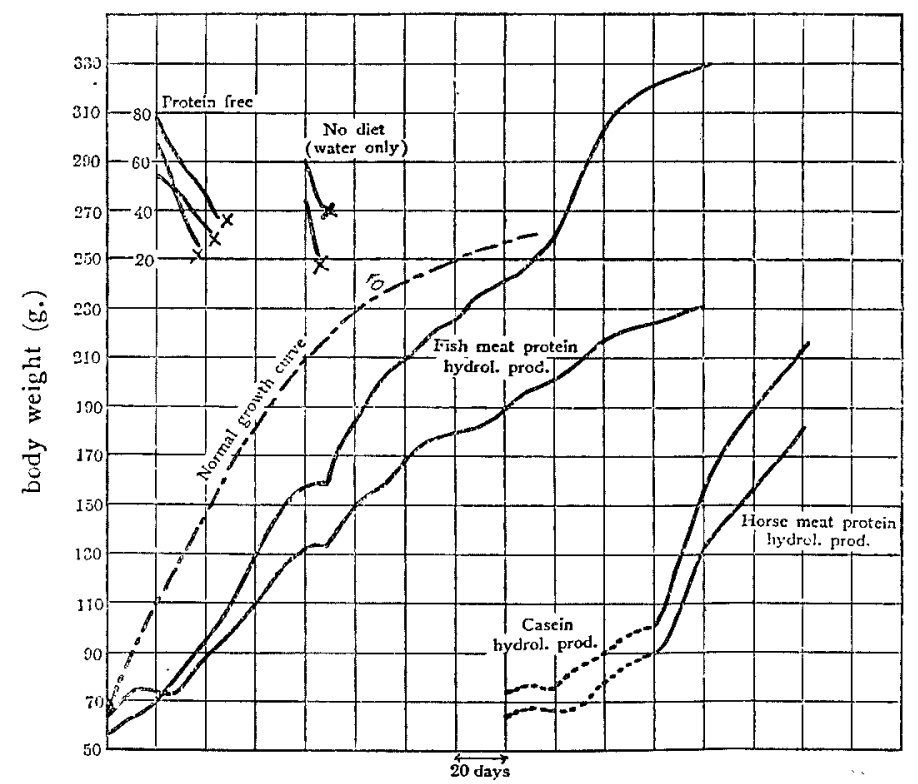

Fig. III.

* The butter used in the experiment was extracted with ether and the ether-soluble portion was evaporated off. 
Experiments with decomposition products of fish meat protein.

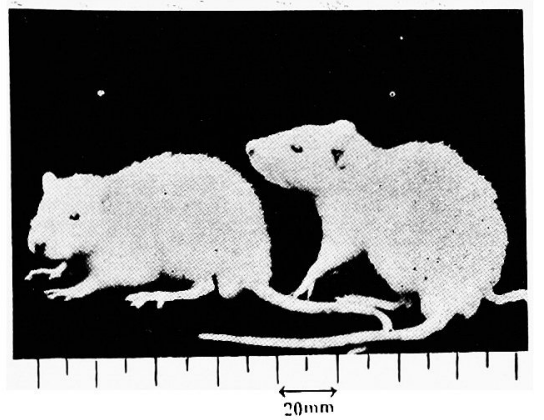

$56 \mathrm{~g} . \quad 62 \mathrm{~g}$.

Fig. VII, Before the experiment.

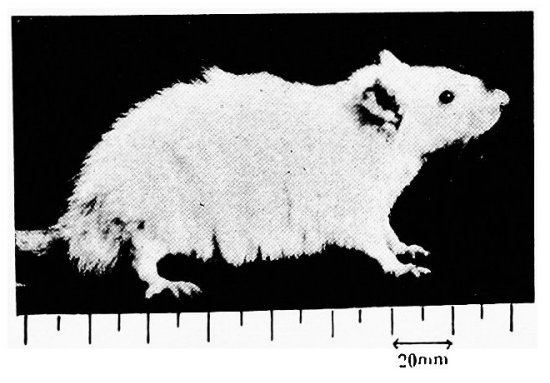

$330 \mathrm{~g}$.

Fig. VIII. After 8 months.

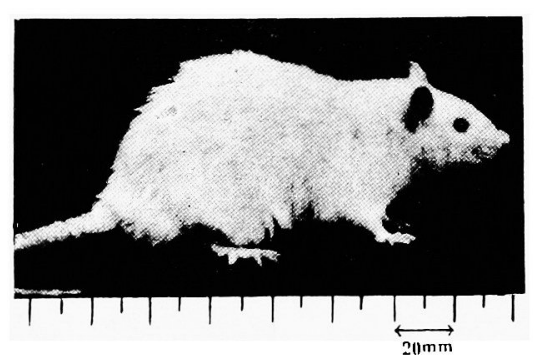

$231 \mathrm{~g}$.

Fig. IX. After 8 months.

Experiments with decomposition products of horse meat protein.

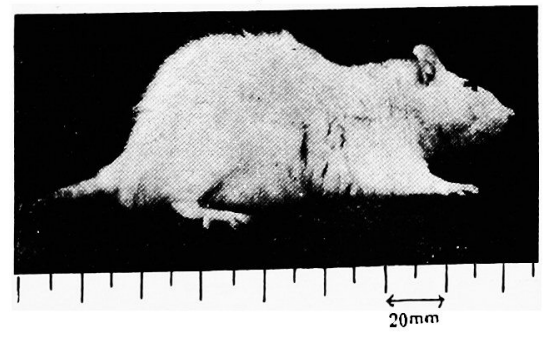

$192 \mathrm{~g}$.

Fig. $X$. After 2 months.

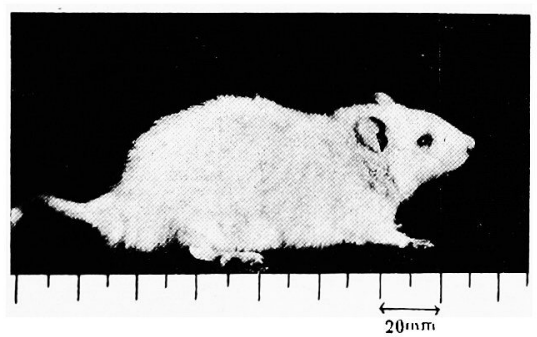

$220 \mathrm{~g}$.

Fig. XI. After 2 months. 
Experiments with acid hydrolytic product Supplemented with racemic tryptophane.

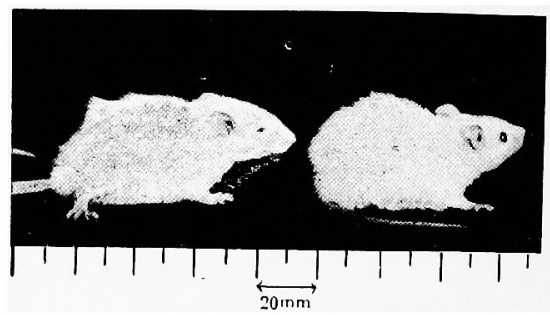

$64 \mathrm{~g}$.

$65 \mathrm{~g}$.

Fig. XII. Before the experiment.

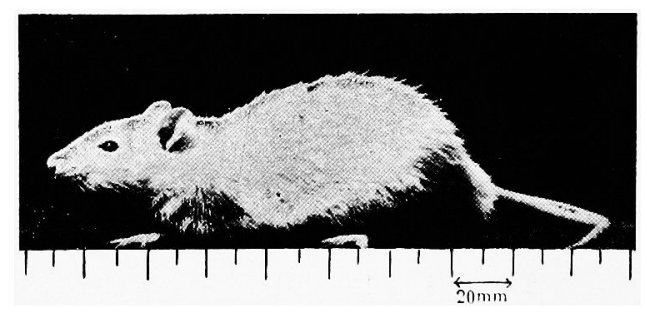

$187 \mathrm{~g}$.

Fig. XIII. After 70 days.

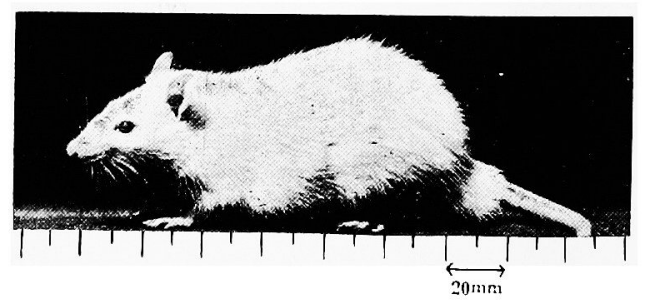

$190 \mathrm{~g}$.

Fig. XIV. After 70 days.

Experiment with acid hydrolytic product of fish meat protein.

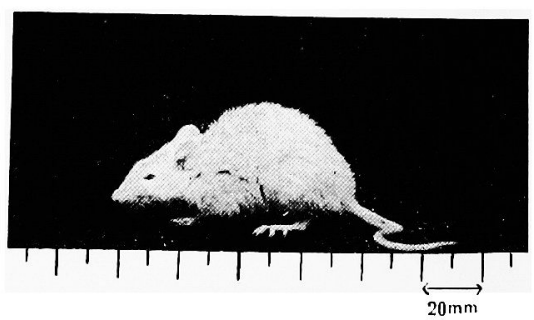

$40 \mathrm{~g}$.

Fig. XV. After 30 days. 


\section{Experiments with the acid and the baryta hydrolytic products separately.}

The acid and the baryta hydrolytic products, complety free from biuret reaction were prepared from fish meat protein, as well as from horse meat protein, in the same manner as described before. Young rats were fed first on the diet consisting of :

$\begin{array}{lrlr}\text { Fish meat protein } & 15 \% & \text { Starch } & 65 \% \\ \text { Butter (ether soluble part) } & 15 \% & \text { McCollum's salt mixture } & 5 \% \\ \text { Alcohol extract of yeast } & 5 \% & & \end{array}$

and let grow for 8 days. When the whole of the protein was replaced by each hydrolysate, the animals soon began to decline in body weights, and finally succumbed (Fig. IV, XV).

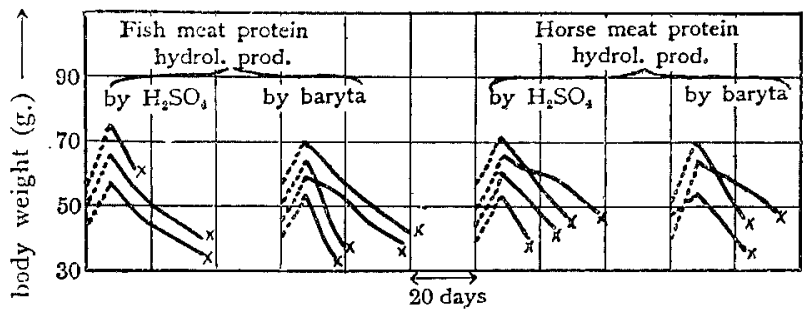

Fig. VI. Experiments with the acid or the baryta hydrolytic products. -.... fish meat protein.

hydrolytic product of protein.

\section{Experiments with the acid hydrolytic products supplemented with tryptophane.}

In the first place, the tryptophane contents of the fish meat protein and its hydrolytic products were estimated according to Matsuyama and Mori's method $^{(s)}$, the tryptophane content of pure casein being assumed to be $1.5 \%$

The results obtained were as follows:

$\begin{array}{lll}\text { Fish meat protein } & 1.24 \% & \text { Acid hydrolytic products } 0.00 \\ \text { Baryta hydrolytic products } & 1.78 \% 6\end{array} \quad$.

From these results, it can be seen that tryptophane is completely decomposed by boiling with acid, but it is not destroyed, by treating with baryta. Intending now to decide whether the indispensable factor in the baryta hydrolytic product, which is lacking in the acid hydrolytic products, is tryptophane only the baryta hydrolytic products were fractionated by mercuric sulphate into two parts; i.e. the one, consisting solely of crystalline tryptohane and the other, the filtrate from $\mathrm{HgSO}_{4}$-preciptate containing no tryptophane.

(8) Matsuya \& Mori: J. Chem, Soc. Tap., 44 (1923), 377. 
Mercury and sulphuric acid in the filtrate were removed by hydrogen sulphide and baryta respectively, the resulting filtrate was neutralized with dilute caustic soda, and then evaporated to dryness at lower temperature. From $200 \mathrm{~g}$. of fish meat protein, $1.5 \mathrm{~g}$. of crystalline tryptophane and $130 \mathrm{~g}$. of the filtrate part were obtained.

Tryptophane obtained as above stated was optically inactive, and gave the following analytical result.

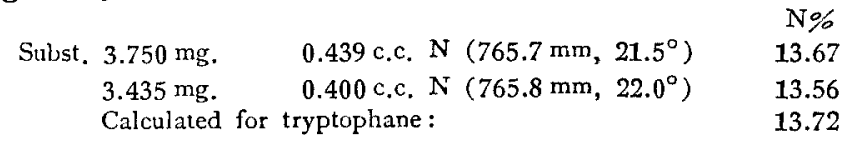

Rats were fed first on fish meat protein and let grow for 8 days, then the protein was replaced by its acid hydrolysate, so the rats began to lose their body weights, owing to the lack of tryptophane. Then two rats were supplied with racemic tryptophane ${ }^{; *}$ to the extent of $3 \%$ of the acid hydrolysate, and to the other two rats the filtrate part of the baryta hydrolysate was given repalacing half the quantity of the acid hydrolysate. Hereupon, a sudden increase of body weight was resulted in the former case namely on the ration containing tryptophane. Rats grew normally from $64 \mathrm{~g}$. and $65 \mathrm{~g}$. up to $187 \mathrm{~g}$. and $190 \mathrm{~g}$. respectively in 70 days, while the rats receiving the latter

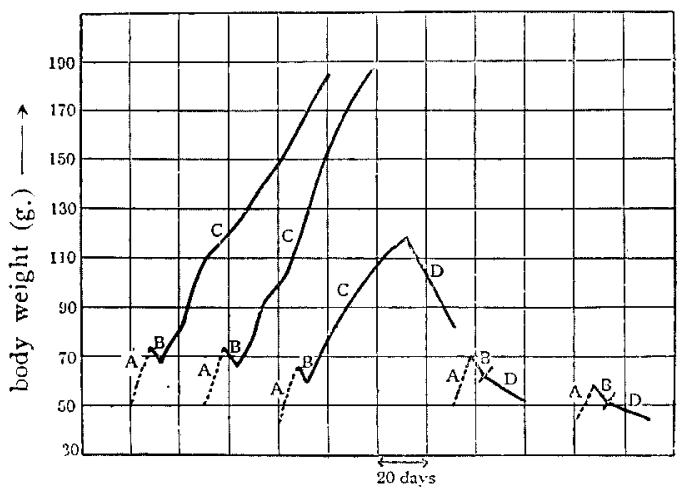

Fig. V. Experiments with acid hydrolytic product supplemented with tryptophane.

A : Fish meat protein; B: Acid hydrol, prod.

C: B. suppl, with tryptophane (3\% of the acid hydrol. prod.)

D: B. suppl. with the filtrate part in the baryta hydrol. prod. ration lost their body weights remakably. To the remaining one, supplied with tryptophane, and grown vigorously for 38 days was given the baryta hydrolysate, replacing half the quantity of the acid hydrolysate, tryptophane being omitted. In this case also, the rat soon began to decline in body weights (Fig. V, XII, XIII, XIV). From these results, it may be seen that the filtrate part of the baryta hydrolysate has no supplementing effect on the acid hydrolysate, but, what should give us con-

cern is that some toxic substance might contaminate the filtrate during the process of fractionation with mercuric sulphate, so the experiments were repeated with the following scheme:

* $20 \mathrm{~g}$. of racemic tryptophane was prepared from $2.5 \mathrm{~kg}$. of casein by boiling with baryta. 
Rats were fed first 20 days on the diet consisting of :
Acid hydrolytic products $7.5 \%$
Baryta hydrolylic products $7.5 \%$
Starch
$65.0 \%$
Butter (ether soluble pait) $\mathbf{1 5 . 0 \%}$
McCollum's salt mixture $\quad 5.0 \%$
Alcohol extract of yeast $\quad 5.0 \%$

After 20 days, when the baryta hydrolytic products were replaced by its tryptophane-free filrate part, the growing rats soon began to loose their weights remarkable. By adding tryptophane (3\% of the hydrolytic products) the rats revived suddenly and began to grow vigorously. After 20 days, the filtrate part was removed from the above diet but no effect on growth was observed and the rats continued to grow normally as before (Fig. VI). From these results, the author wishes to conclude that the acid hydrolytic products of protein, when supplemented with tryptophane, can replace the protein in diets completely.

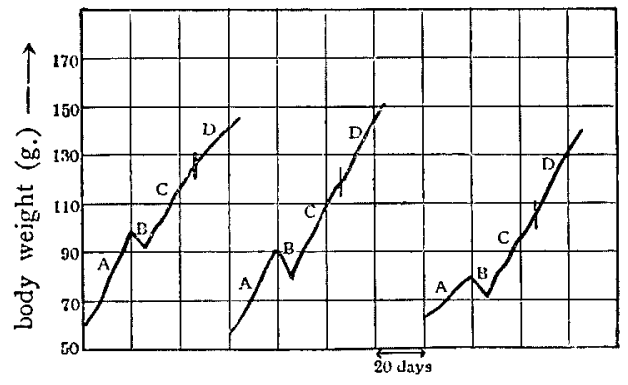

Fig. VI, Similar experiments as shown in Fig. II.

A: Mixture of the acid and the baryta hydrol. prod.

B: Acid hydrol, prod. and the filtrate part in the baryta hydrol. prod.

C: B. suppl. with tryptophane (3\% of the hydrol. prod.)

D : Acid hydrol. prod. suppl, with $3 \%$ of tryptophane.

In conclusion, the author wishes to expess his deepest obligations to Prof. U. Suzuki for his kind directions throughout this work. 